\title{
Osteobrama bhimensis (Cypriniformes: Cyprinidae): a junior synonym of 0 . vigorsii
}

\author{
Shrikant S. Jadhav ${ }^{1}$, Mandar Paingankar ${ }^{2} \&$ Neelesh Dahanukar ${ }^{3}$ \\ ${ }^{1}$ Zoological Survey of India, Western Regional Centre, Vidyanagar, Akurdi, Pune, Maharashtra 411044, India \\ ${ }^{2}$ Prerana Heights, Flat No. B13, Balaji Nagar, Dhankawadi, Pune, Maharashtra 411043, India \\ ${ }^{3}$ Indian Institute of Science Education and Research, Sai Trinity, Garware Circle, Pune, Maharashtra 411021, India \\ Email: ${ }^{1}$ shrikantj123@yahoo.com, ${ }^{2}$ mandarpaingankar@gmail.com, ${ }^{3}$ n.dahanukar@iiserpune.ac.in (corresponding author)
}

Date of publication (online): 26 September 2011 Date of publication (print): 26 September 2011 ISSN 0974-7907 (online) | 0974-7893 (print)

Editor: Anonymity requested

\section{Manuscript details:}

Ms \# 02841

Received 22 June 2011

Final received 17 July 2011

Finally accepted 15 August 2011

Citation: Jadhav, S.S., M. Paingankar \& N Dahanukar (2011). Osteobrama bhimensis (Cypriniformes:Cyprinidae): a junior synonym of O. vigorsii. Journal of Threatened Taxa 3(9): 2078-2084.

Copyright: (C) Shrikant S. Jadhav, Mandar Paingankar \& Neelesh Dahanukar 2011 Creative Commons Attribution 3.0 Unported License. JoTT allows unrestricted use of this article in any medium for non-profit purposes, reproduction and distribution by providing adequate credit to the authors and the source of publication.

Author Detail: Shrikant S. Jadhav is Scientist $A$ at the Zoological Survey of India, Western Regional Centre, Pune. He works on taxonomy and distribution of freshwater fishes and has published several papers in this area. MANDAR PAINGANKAR is a molecular biologist and works on vector biology with an emphasis on host parasite interactions. He works on animal ecology as a hobby. Neelesh Dahanukar works in ecology and evolution with an emphasis on mathematical and statistical analysis. $\mathrm{He}$ is also interested in taxonomy, distribution patterns and molecular phylogeny of freshwater fishes.

Author Contribution: SSJ and ND put forth the concept. SSJ, MP and ND collected the data, analyzed the data and wrote the paper.

Acknowledgements: We are thankful to $\mathrm{Dr}$ R.M. Sharma, Scientist-D and Officer-in-charge, Zoological Survey of India, Western Regional Centre, Akurdi, Pune, and Dr. G.M. Yazdani for encouragement and support. We are grateful to Varsha Mysker for providing two specimens of Osteobrama vigorsii from Bhima River at Kollakur, Karnataka. We are also grateful to two anonymous referees for critical comments on an earlier draft of our manuscript.

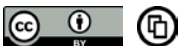

OPEN ACCESS | FREE DOWNLOAD
Abstract: Osteobrama bhimensis (Singh \& Yazdani) was described from the Ujani wetland on Bhima River in Maharashtra, India, about $100 \mathrm{~km}$ downstream of the type locality of O. vigorsii (Sykes). Based on examination of the type material of O. bhimensis and comparison with $\mathrm{O}$. vigorsii collected from different localities in the Krishna and Godavari River systems, we show that $O$. bhimensis is conspecific with $O$. vigorsii.

Keywords: Conspecific, junior synonym, Osteobrama bhimensis, Rohtee vigorsii.

\section{INTRODUCTION}

Sykes (1839) described Rohtee vigorsii (now Osteobrama) from the Bhima River at Pairgaon (approx. $18.506^{\circ} \mathrm{N} \& 74.704^{\circ}$ E). Although the types of this species are missing (Eschmeyer \& Fricke 2011), Sykes (1841) provided a clear illustration of the species and gave an adequate description for purposes of identification. The species is widely distributed in the Krishna, Godavari and Mahanadi river systems of peninsular India and is common throughout its range (Dahanukar 2011). Singh \& Yazdani (1992) described Osteobrama bhimensis from the Ujani Wetland on Bhima River, about $100 \mathrm{~km}$ downstream of the type locality of $O$. vigorsii. Osteobrama bhimensis has since been considered a valid species by most authors (e.g., Menon 1999; Jayaram 2010). Even though Singh \& Yazdani (1992) considered $O$. bhimensis to be closely related to O. cotio, owing to the lack of barbels, their figure of $O$. bhimensis resembles $O$. vigorsii more than it does O. cotio. Singh \& Yazdani (1992) did, however, mention the similarity between $O$. bhimensis and $O$. vigorsii and sought to distinguish the two species through a number of characters (discussed below).

Recently we had an opportunity to study all the type material, comprising the holotype and five paratypes, of $O$. bhimensis currently in the collection of the Zoological Survey of India, Western Regional Centre, Pune. We compared the type material of $O$. bhimensis with specimens of $O$. vigorsii from the Krishna and Godavari river systems. Our study suggests that $O$. bhimensis and $O$. vigorsii are conspecific.

\section{METHODS}

\section{Data collection}

The type material of Osteobrama bhimensis, comprising of the holotype and five paratypes, was available in the fish collection of the 
Zoological Survey of India, Western Regional Centre, Pune (ZSI Pune). Specimens of $O$. vigorsii and $O$. cotio peninsularis were available in the Wildlife Information Liaison Development, Coimbatore (WILD) and ZSI Pune. Morphometric and meristic data were recorded following Jayaram (2010). Measurements were taken point to point using dial calipers to the nearest hundredth of an inch and then converted to millimetres. Subunits of the body are presented as a percent of standard length (SL) and subunits of the head are presented as a percent of head length (HL). All pored scales were counted for reporting the lateral lines scales. We dissected three specimens of $O$. vigorsii $(\mathrm{P} / 2671,110 \mathrm{~mm} \mathrm{SL} ; \mathrm{P} / 2672$, $105 \mathrm{~mm} \mathrm{SL}$ and $\mathrm{P} / 2673,128 \mathrm{~mm} \mathrm{SL}$ ) to resolve the structure of the urohyal bone.

\section{Material examined}

Osteobrama bhimensis: Holotype, 06.ix.1989, Bhima River, Saha Village (approx. $18.133^{\circ} \mathrm{N} \&$ $75.093^{\circ} \mathrm{E}$ ), Indapur Taluka, Pune District, Maharashtra, coll. D.F. Singh (ZSI Pune P/1235). Paratypes, 5 ex., collection data same as holotype (ZSI Pune P/1236).

Osteobrama vigorsii: 1 ex., WILD-11-PIS-017, Mula-Mutha River at Yerawada $\left(18.542^{\circ} \mathrm{N}\right.$ \& $73.877^{\circ} \mathrm{E}$ ), collected on 14.i.2011 by N. Dahanukar \& M. Paingankar; 1 ex., ZSI Pune P/2670, Bhima River at Koregaon-Bhima $\left(18.647^{\circ} \mathrm{N} \& 74.054^{\circ} \mathrm{E}\right)$, collected on 25.v.2011 by N. Dahanukar \& M. Paingankar; 1 ex., ZSI Pune P/2672, Mula-Mutha River at Yerawada $\left(18.542^{\circ} \mathrm{N} \& 73.877^{\circ} \mathrm{E}\right)$, collected on $07 . i .2011$ by N. Dahanukar \& M. Paingankar; 1 ex., ZSI Pune $\mathrm{P} / 2673$, Krishna River at Wai $\left(17.956^{\circ} \mathrm{N} \& 73.879^{\circ} \mathrm{E}\right)$, collected in March 2011 by N. Dahanukar \& M. Paingankar; 1 ex., ZSI Pune P/2671, Nira River at Bhor $\left(18.153^{\circ} \mathrm{N}, 73.843^{\circ} \mathrm{E}\right)$, collected in December 2009 by N. Dahanukar \& M. Paingankar; 1 ex., ZSI Pune P/2674, Wasumbre tank (approx. $17.298^{\circ} \mathrm{N}$, $74.579^{\circ} \mathrm{E}$ ) in Sangli District, collected on 16.vi.1979 by A.S. Mahabal; 1 ex., ZSI Pune P/2676, Mutha River at Warje $\left(18.481^{\circ} \mathrm{N}, 73.816^{\circ} \mathrm{E}\right)$, collected on 24 February 1999 by N. Dahanukar; 1 ex., ZSI Pune $\mathrm{P} / 2675$, Mula River at Aundh $\left(18.568^{\circ} \mathrm{N} \& 73.811^{\circ} \mathrm{E}\right)$, collected on 02.vi.1999 by N. Dahanukar; 2 ex., unregistered, Bhima River at Kollakur $\left(17.086^{\circ} \mathrm{N} \&\right.$ $76.764^{\circ} \mathrm{E}$ ), collected on 10.v.2011 by Varsha Mysker; 3 ex., ZSI Pune P/2105, Godavari River at Kaigaon (approx. $19.624^{\circ} \mathrm{N}, 75.026^{\circ} \mathrm{E}$ ) in Gangapur Taluka,
Aurangabad, collected on 13.x.1999 by P.P. Kulkarni.

Osteobrama cotio peninsularis: 1 ex., WILD-11PIS-015, Mula-Mutha River at Yerawada $\left(18.542^{\circ} \mathrm{N}\right.$ \& $73.877^{\circ} \mathrm{E}$ ), collected on 07.i.2011 by N. Dahanukar \& M. Paingankar; 1 ex., ZSI Pune P/2595, Indrayani River at Markal $\left(18.673^{\circ} \mathrm{N} \& 73.984^{\circ} \mathrm{E}\right)$, collected during 2009-2010 by N. Dahanukar \& M. Paingankar; 1 ex., ZSI Pune $\mathrm{P} / 2443$, Nira River at Bhor $\left(18.153^{\circ} \mathrm{N}\right.$ \& $73.843^{\circ} \mathrm{E}$ ), collected on 01.i.2011 by N. Dahanukar \& M. Paingankar; 1 ex., ZSI Pune P/2684, Mula River at Paud $\left(18.529^{\circ} \mathrm{N} \& 73.611^{\circ} \mathrm{E}\right)$, collected on 08.vi.2011 by N. Dahanukar \& M. Paingankar; 3 ex., ZSI Pune $\mathrm{P} / 2685$, Mula-Mutha River at Yerawada $\left(18.543^{\circ} \mathrm{N} \&\right.$ $73.879^{\circ} \mathrm{E}$ ), collected on $16 . v i .2011$ by N. Dahanukar \& M. Paingankar.

\section{RESULTS AND DISCUSSION}

One of the most important characters that Singh \& Yazdani (1992) used for diagnosing Osteobrama bhimensis was the absence of barbels. Our study of the type material of $O$. bhimensis revealed that the holotype and all the paratypes of $O$. bhimensis do in fact possess a pair of rudimentary maxillary barbels (Image 1), a character state also present in O. vigorsii.
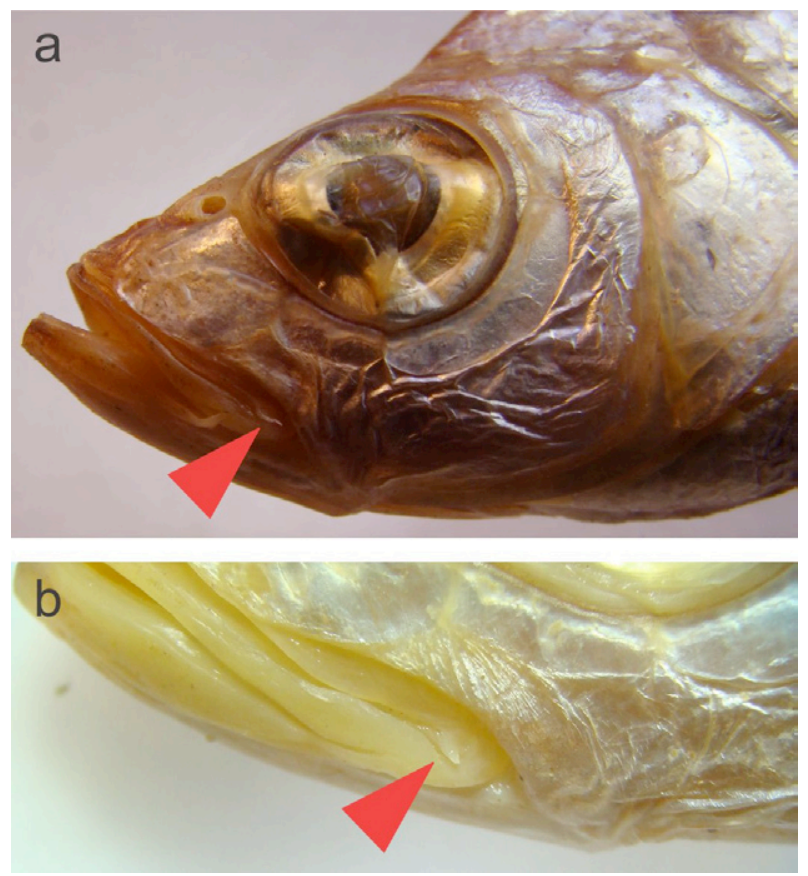

Image 1. Rudimentary maxillary barbels in Osteobrama bhimensis (a) holotype (ZSI Pune P/1235) and (b) one of the paratypes (ZSI Pune P/1236). 
Indeed, if the character state 'barbels present' were applied to specimens of $O$. bhimensis using Singh \& Yazdani's (1992) own key, the species keys out as $O$. vigorsii.

Singh \& Yazdani (1992) suggested that $O$. bhimensis is related to $O$. cotio and compared it with two subspecies of $O$. cotio, namely $O$. cotio cotio and $O$. cotio cunma. Even though these authors did not explicitly mention why they consider $O$. bhimensis to be affined to $O$. cotio, it appears they considered the absence of barbels in $O$. bhimensis to be synapomorphic in the $O$. bhimensis-O. cotio group. Our data, however, does not suggest a closer relationship between $O$. bhimensis and $O$. cotio than that between the former species and $O$. vigorsii, for two reasons. First, the holotype and all the paratypes of $O$. bhimensis do possess rudimentary barbels (Image 1). Second, the morphometric and meristic data of $O$. bhimensis do not coincide substantially with $O$. cotio, an observation that was also made by Singh \& Yazdani
(1992). Interestingly, Singh \& Yazdani (1992) did not compare $O$. bhimensis with $O$. cotio peninsularis described by Silas (1952) from Poona [= Pune], which is close to the type locality of $O$. bhimensis. Our comparison suggests that $O$. bhimensis differs from $O$. cotio peninsularis in a number of characters including ii22-ii24 (vs. ii27-ii32 in O. c. peninsularis) anal fin rays, 26-30 (vs. 17-18) predorsal scales, 72-79 (vs. 55-56) lateral-line scales and head length 26.0-28.3 $\%$ SL (vs. $22.3-24.0 \% \mathrm{SL}$ ).

The type material of $O$. bhimensis and the figure given in Singh \& Yazdani (1992, fig. 1), however, is consistent with Sykes' (1842) description and figure of $O$. vigorsii, a species very widely distributed across the Krishna and Godavari river systems of the northcentral part of the peninsular India. A comparison of the morphometric data of the type series of $O$. bhimensis with the material of $O$. vigorsii referred to herein, from a number of locations across the Krishna River and Godavari basins (Fig. 1), suggests that

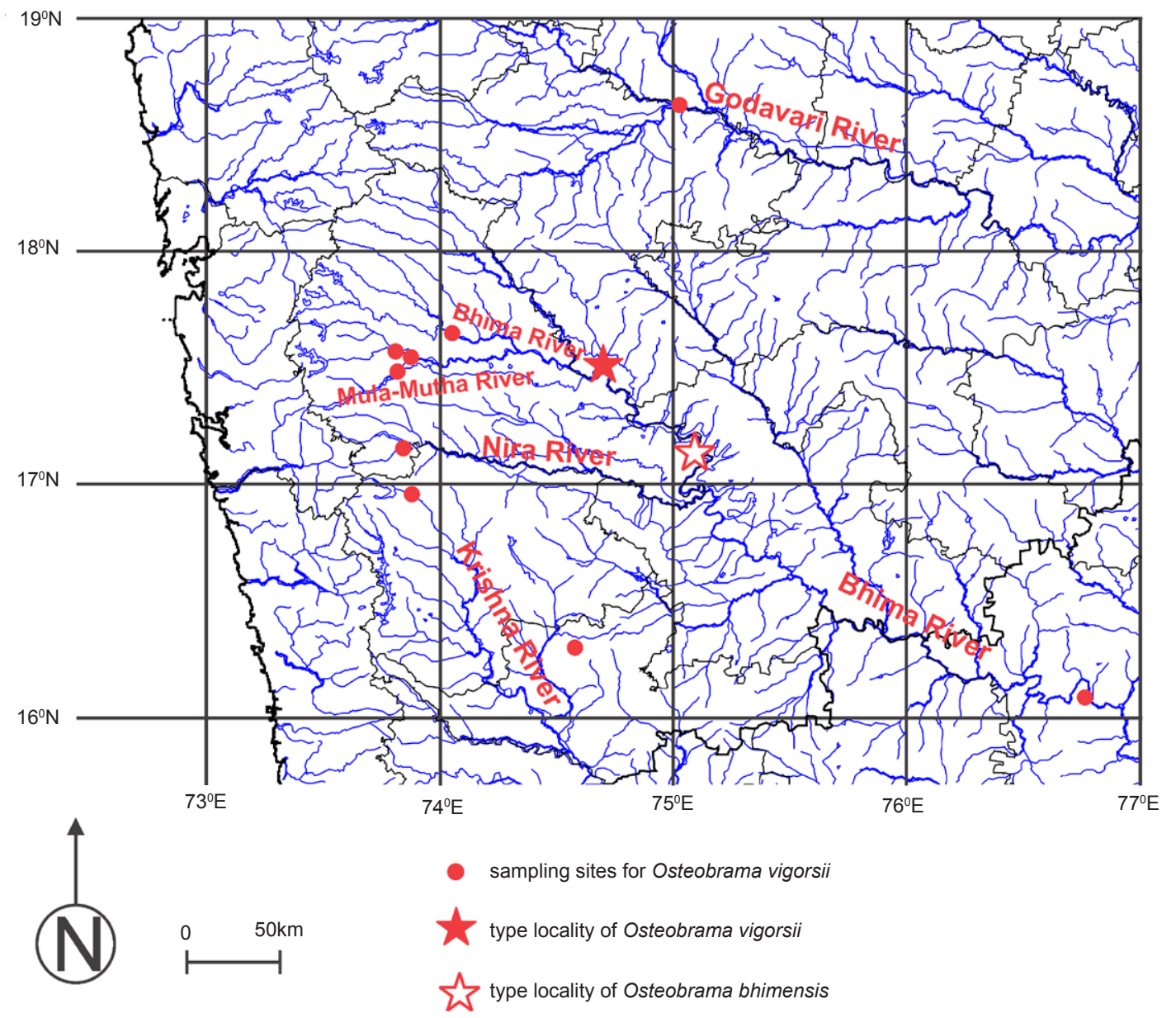

Figure 1. Study area showing sampling sites and type localities of Osteobrama vigorsii and O. bhimensis. 
Table 1. Comparison of ranges of morphometric and meristic data of the type series of Osteobrama bhimensis (ZSI Pune P/1235 and ZSI Pune P/1236, total 6 specimens) and the 13 specimens of O. vigorsii listed in Material Examined.

\begin{tabular}{|c|c|c|}
\hline Character & $\begin{array}{l}\text { Osteobrama bhimensis } \\
\qquad(\mathrm{N}=6)\end{array}$ & $\begin{array}{c}\text { Osteobrama vigorsii } \\
\qquad(\mathrm{N}=13)\end{array}$ \\
\hline \multicolumn{3}{|l|}{ Morphometrics } \\
\hline Total length (mm) & $168-270$ & $123-190$ \\
\hline Standard length (mm) & $135-212$ & $96.4-147$ \\
\hline \multicolumn{3}{|l|}{ As a percentage of $S L$} \\
\hline Body depth & $30.0-33.1$ & $30.6-35.6$ \\
\hline Head length & $26.0-28.3$ & $24.4-28.7$ \\
\hline Predorsal length & $52.0-54.6$ & $50.2-54.8$ \\
\hline Dorsal to caudal length & $50.9-53.5$ & $50.1-57.5$ \\
\hline Distance between pectoral and ventral & $15.7-17.9$ & $15.8-18.4$ \\
\hline Distance between ventral to anal fin & $19.1-22.1$ & $17.4-38.9$ \\
\hline Pectoral to anal distance & $34.3-39.5$ & $33.9-40.8$ \\
\hline Preanal length & $60.4-63.1$ & $56.7-63.2$ \\
\hline Caudal peduncle length & $16.4-19.2$ & $15.0-19.7$ \\
\hline Caudal peduncle depth & $10.4-11.2$ & $10.3-11.7$ \\
\hline \multicolumn{3}{|l|}{ As a percentage of $H L$} \\
\hline Snout length & $23.0-26.8$ & $25.3-30.6$ \\
\hline Eye diameter & $26.9-30.2$ & 23.9-30.7 \\
\hline Interorbital width & $21.7-23.6$ & $19.7-26.4$ \\
\hline \multicolumn{3}{|l|}{ Meristics } \\
\hline Predorsal scales & $26-30$ & $26-28$ \\
\hline Lateral line scales & $72-79$ & $75-78$ \\
\hline Scale rows between lateral line and base of pelvic fin & $11-11 \frac{1}{2}$ & $11-11 \frac{1}{2}$ \\
\hline Scale rows between lateral line and origin of dorsal fin & $13-15$ & $13-14$ \\
\hline Dorsal fin rays & 1,8 & 1,8 \\
\hline Pectoral fin rays & $\mathrm{i}, 13-\mathrm{i}, 14$ & $\mathrm{i}, 13-\mathrm{i}, 14$ \\
\hline Ventral fin rays & $\mathrm{i}, 8-\mathrm{i}, 9$ & $\mathrm{i}, 8-\mathrm{i}, 9$ \\
\hline Anal fin rays & ii,22-ii,24 & ii,22-ii,23 \\
\hline
\end{tabular}

the morphometric and meristic data of $O$. bhimensis substantially overlap with those of $O$. vigorsii (Table 1, Appendix A, B). Further, comparison of images of the types of $O$. bhimensis with those of $O$. vigorsii from a variety of sources, and the illustration of Sykes (1841) iteself, shows a remarkable resemblance (Image 2).

Although Singh \& Yazdani (1992) were aware of the resemblance between $O$. bhimensis and $O$. vigorsii, they separated the former from the latter based on the absence of barbels (vs. presence), 13-17 transverse scale rows between lateral line and pelvic fin base (vs. 11-11/2 ), the possession of 24-32 predorsal scales (vs. 33-37), and the structure of urohyal. As already mentioned, the entire type series of $O$. bhimensis possesses rudimentary maxillary barbels, a character state shared with $O$. vigorsii. Although Singh \&
Yazdani (1992, Table 2) mention the number of transverse scale rows between lateral line and pelvic fin base as $13-15$, we count 11 or $11 \frac{1}{2}$ (Table 1 ), which is the same range also for $O$. vigorsii (Hora \& Misra 1940; Singh \& Yazdani 1992; see also Table 1). The predorsal scales of $O$. bhimensis and $O$. vigorsii also have overlapping ranges (Table 1).

An additional difference that Singh \& Yazdani (1992) used to differentiate $O$. bhimensis from $O$. vigorsii was the shape of the urohyal. This is a single median triradiate bone with the anterior tip connected to the ventral hypohyals, the antero-dorsal part of which is connected to the first basibranchial and the posterior part of which is connected to the pectoral girdle by means of muscles (Johal et al. 2000). The shape of the urohyal of $O$. vigorsii (Image 3) matches 
Image 2. Osteobrama bhimensis and $O$. vigorsii. (a) Osteobrama bhimensis holotype (ZSI Pune P/1235, 138mm $\mathrm{SL}$ ), (b) O. bhimensis paratype (ZSI Pune P/1236, 143mm $\mathrm{SL})$, (c) $O$. vigorsii from Bhima River at Koregaon-Bhima (ZSI Pune P/2670, 110mm SL), (d) O. vigorsii from Nira River at Bhor (ZSI Pune P/2671, 110mm SL), (e) O. vigorsii from Bhima River at Kollakur (unregistered, 126mm SL) and (f) original drawing of $O$. vigorsii, reproduced laterally inverted, from Sykes (1841).
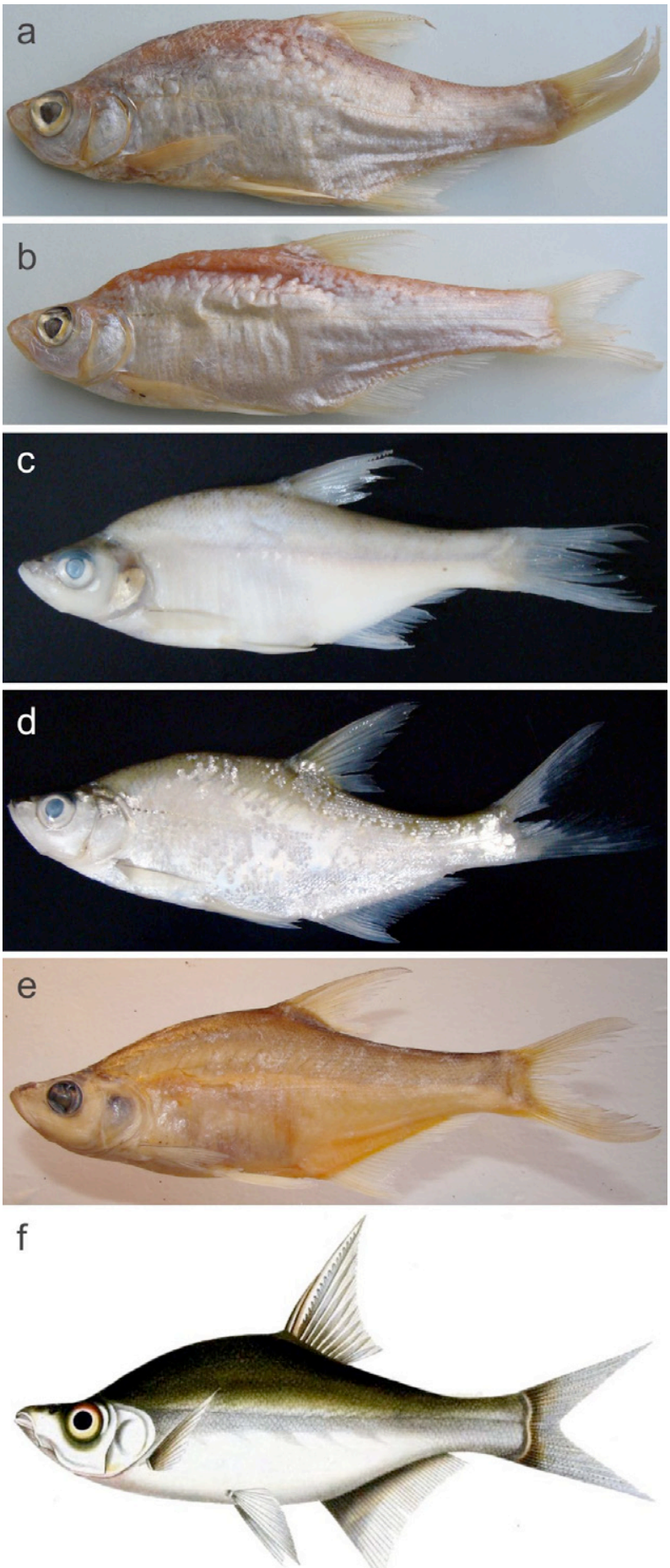

Image 3. Urohyal bone (ZSI Pune P/2683) of Osteobrama vigorsii (P/2673, 128mm SL). (a) Lateral view and (b) dorsal view.
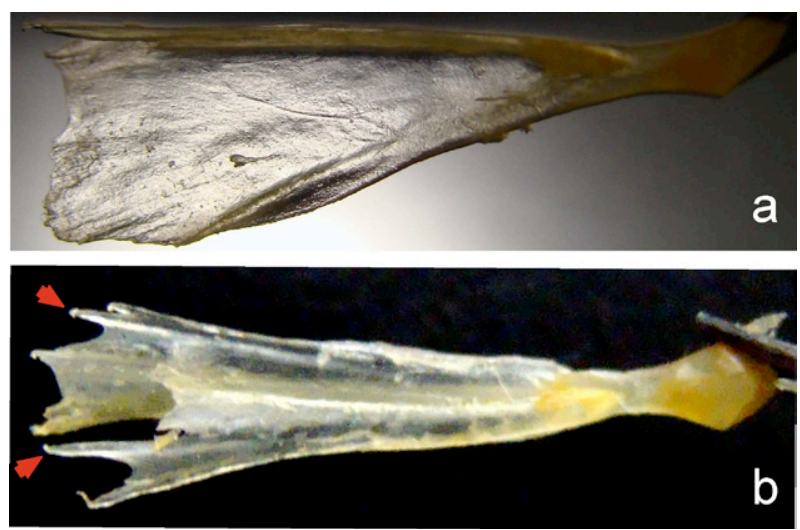

that of $O$. bhimensis as illustrated in fig. 2 of Singh \& Yazdani (1992). Singh \& Yazdani (1992) suggested that the urohyal of $O$. vigorsii exhibits a radial process on the vertical plate, which is absent in $O$. bhimensis. However, in the three specimens of $O$. vigorsii we dissected, there is no such radial process (note that in Image $3 \mathrm{a}$ the thickened area on the lower surface is merely an undulation, not a process). Further, Singh \& Yazdani (1992) mention that the dorsal spread ends in equal wings in $O$. bhimensis, while it ends in unequal wings in $O$. vigorsii. Our specimens of $O$. vigorsii show the dorsal spread to end in two equal wings (Image 3b). Therefore, the difference between the urohyals of $O$. bhimensis and $O$. vigorsii mentioned by Singh \& Yazdani (1992) do not, in fact, exist. We did not dissect any of the type specimens of $O$. bhimensis. However, it is important to note that even though Singh \& Yazdani (1992) mentioned that they studied the urohyal bone of $O$. bhimensis and $O$. vigorsii, they omitted to mention which specimens were used for their study. It is clear that none of the types of $O$. bhimensis have been dissected or cleared and stained.

The present study shows, therefore, that all the differences stated by Singh \& Yazdani (1992) as distinguishing $O$. bhimensis from $O$. vigorsii do not in fact exist: the two nominal species are in fact conspecific and, $O$. vigorsii being the senior one, is valid, while $O$. bhimensis must now be placed in its synonymy.

Dahanukar (2010) assessed the IUCN conservation status of Osteobrama bhimensis as Endangered under criteria B1ab(iii)+2ab(iii) (IUCN 2001) owing to the 
Appendix A. Morphometric and meristic data of type material of Osteobrama bhimensis.

\begin{tabular}{|c|c|c|c|c|c|c|}
\hline \multirow{2}{*}{ Character } & \multirow{2}{*}{$\begin{array}{c}\text { Holotype } \\
\text { (ZSI Pune P/1235) }\end{array}$} & \multicolumn{5}{|c|}{ Paratypes (ZSI Pune P/1236) } \\
\hline & & $\# 1$ & \#2 & \#3 & $\# 4$ & \#5 \\
\hline \multicolumn{7}{|l|}{ Morphometric } \\
\hline Total length (mm) & 173 & 270 & 178 & 182 & 171 & 168 \\
\hline Standard length (mm) & 138 & 212 & 146 & 143 & 137 & 135 \\
\hline \multicolumn{7}{|l|}{ As a percentage of $S L$} \\
\hline Body depth & 30.1 & 31.7 & 31.5 & 33.1 & 31.3 & 30.0 \\
\hline Head length & 26.4 & 26.0 & 28.0 & 28.3 & 27.3 & 26.6 \\
\hline Predorsal length & 52.0 & 53.4 & 52.9 & 54.6 & 54.6 & 54.4 \\
\hline Dorsal to caudal length & 53.3 & 52.4 & 50.8 & 53.5 & 51.2 & 51.3 \\
\hline Distance between pectoral and ventral & 17.9 & 16.9 & 15.7 & 17.2 & 16.8 & 17.2 \\
\hline Distance between ventral to anal fin & 20.5 & 19.7 & 19.0 & 20.8 & 22.1 & 21.3 \\
\hline Pectoral to anal distance & 39.5 & 36.5 & 34.3 & 37.3 & 35.9 & 38.8 \\
\hline Preanal length & 61.5 & 60.8 & 60.4 & 62.3 & 63.1 & 62.9 \\
\hline Caudal peduncle length & 18.2 & 18.3 & 17.5 & 18.0 & 16.4 & 19.2 \\
\hline Caudal peduncle depth & 11.0 & 11.0 & 10.3 & 11.1 & 11.2 & 11.0 \\
\hline \multicolumn{7}{|l|}{ As a percentage of $H L$} \\
\hline Snout length & 24.7 & 24.3 & 26.4 & 26.9 & 23.3 & 22.8 \\
\hline Eye diameter & 30.1 & 27.0 & 26.9 & 29.6 & 27.5 & 28.1 \\
\hline Interorbital width & 22.5 & 21.9 & 21.8 & 23.0 & 23.5 & 22.0 \\
\hline \multicolumn{7}{|l|}{ Meristic } \\
\hline Predorsal scales & 27 & 28 & 30 & 27 & 27 & 26 \\
\hline Lateral line scales & 74 & 79 & 75 & 72 & 74 & 75 \\
\hline Scales between lateral line and pelvic fin & 11.5 & 11.5 & 11.5 & 11.5 & 11.5 & 11 \\
\hline Scales between lateral line and dorsal fin & 13 & 14 & 14 & 14 & 15 & 14 \\
\hline Dorsal fin rays & 1,8 & 1,8 & 1,8 & 1,8 & 1,8 & 1,8 \\
\hline Pectoral fin rays & $\mathrm{i}, 14$ & $\mathrm{i}, 14$ & $\mathrm{i}, 14$ & $\mathrm{i}, 14$ & $\mathrm{i}, 13$ & $\mathrm{i}, 14$ \\
\hline Ventral fin rays & $\mathrm{i}, 8$ & $\mathrm{i}, 9$ & $\mathrm{i}, 9$ & $\mathrm{i}, 8$ & $\mathrm{i}, 9$ & $\mathrm{i}, 9$ \\
\hline Anal fin rays & $\mathrm{ii}, 22$ & $\mathrm{ii}, 22$ & ii,23 & $\mathrm{ii}, 22$ & $\mathrm{ii}, 24$ & $\mathrm{ii}, 23$ \\
\hline
\end{tabular}

fact that the species is known only from its type locality in the Ujani wetland, with an Extent of Occurrence of $260 \mathrm{~km}^{2}$ and threats to the habitat and the species due to increasing urbanization, agricultural pollution and invasive exotic fishes. Dahanukar (2010) also noted the need to validate the taxonomy of this nominal species because of its remarkable similarity to $O$. vigorsii. In the current study we have established that $O$. bhimensis is not a valid species but a junior subjective synonym of $O$. vigorsii.

\section{REFERENCES}

Dahanukar, N. (2010). Osteobrama bhimensis. In: IUCN 2011. IUCN Red List of Threatened Species. Version 2011.1. <www.iucnredlist.org> . Downloaded on 18 June 2011.

Dahanukar, N. (2011). Osteobrama vigorsii. In: IUCN 2011. IUCN Red List of Threatened Species. Version 2011.1. $<$ www.iucnredlist.org> . Downloaded on 18 June 2011.

Eschmeyer, W.N. \& R. Fricke (eds.) (2011). Catalog of Fishes electronic version. http://research.calacademy.org/ ichthyology/catalog/fishcatmain.asp. Online version dated 5 May 2011. Downloaded on 20 June 2011.

Hora, S.L. \& K.S. Misra (1940). Notes on fishes in the Indian museum. XL. On fishes of the genus Rohtee Sykes. Records of the Indian Museum 42(1): 155-172.

IUCN (2001). IUCN Red List Categories and Criteria: Version 3.1. IUCN Species Survival Commission. IUCN, Gland, Switzerland and Cambridge, UK, ii+30pp.

Jayaram, K.C. (2010). The Freshwater Fishes of The Indian Region. Second Edition. Narendra Publishing House, Delhi, 616pp.

Johal, M.S., H.R. Esmaeili \& K.K. Tandon (2000). Reliability 
Appendix B. Morphometric and meristic data of Osteobrama vigorsii from Krishna and Godavari river systems. Krishna river system: MI - Mula River (ZSI Pune P/2675); Mt - Mutha River (ZSI Pune P/2676); MM1 - Mula-Mutha River (WILD-11-PIS-017); MM2 - Mula Mutha River (ZSI Pune P/2672); BK - Bhima River at Koregaon (ZSI Pune P/2670); N - Nira River at Bhor (ZSI Pune P/2671); BKo1 - Bhima River at Kollakur (unregistered); BKo2 - Bhima River at Kollakur (unregistered); Kr - Krishna River at Wai (ZSI Pune P/2673), S - Wasumbre tank in Sangli District (ZSI Pune P/2674). Godavari river system: 3 examples, Godavari River at Kaigaon (ZSI Pune P/2105).

\begin{tabular}{|c|c|c|c|c|c|c|c|c|c|c|c|c|c|}
\hline \multirow{2}{*}{ Character } & \multicolumn{10}{|c|}{ Krishna river system } & \multicolumn{3}{|c|}{$\begin{array}{l}\text { Godavari river } \\
\text { system }\end{array}$} \\
\hline & $\mathrm{Ml}$ & Mt & MM 1 & MM 2 & BK & $\mathrm{N}$ & BKo 1 & BKo 2 & $\mathrm{Kr}$ & $\mathrm{S}$ & $\# 1$ & \#2 & \#3 \\
\hline \multicolumn{14}{|l|}{ Morphometric } \\
\hline Total length (mm) & 136 & 161 & 156 & 133 & 141 & 146 & 159 & 190 & 164 & 139 & 123 & 125 & 139 \\
\hline Standard length (mm) & 113 & 123 & 122 & 105 & 110 & 110 & 126 & 147 & 128 & 110 & 96.4 & 98.2 & 110 \\
\hline \multicolumn{14}{|l|}{ As a percentage of $S L$} \\
\hline Body depth & 32.1 & 30.6 & 34.3 & 35.0 & 34.6 & 33.5 & 34.0 & 34.4 & 34.5 & 34.3 & 33.7 & 34.0 & 35.6 \\
\hline Head length & 27.3 & 27.4 & 26.2 & 25.6 & 26.7 & 27.6 & 27.0 & 28.7 & 27.3 & 26.1 & 25.2 & 25.1 & 24.4 \\
\hline Predorsal length & 53.4 & 51.1 & 53.4 & 52.0 & 54.8 & 53.7 & 51.7 & 54.0 & 54.6 & 53.2 & 50.5 & 50.2 & 52.9 \\
\hline Dorsal to caudal length & 53.6 & 50.8 & 51.9 & 53.0 & 52.6 & 55.7 & 52.4 & 53.9 & 55.2 & 50.1 & 56.7 & 54.7 & 57.5 \\
\hline Distance between pectoral and ventral & 16.7 & 17.7 & 17.5 & 18.4 & 16.7 & 18.4 & 16.3 & 16.5 & 16.3 & 16.7 & 16.9 & 15.8 & 17.0 \\
\hline Distance between ventral to anal fin & 20.8 & 38.9 & 21.2 & 19.9 & 22.6 & 19.2 & 20.0 & 20.7 & 20.9 & 20.4 & 17.8 & 17.4 & 18.4 \\
\hline Pectoral to anal distance & 35.7 & 36.6 & 37.5 & 36.3 & 38.0 & 34.5 & 40.8 & 36.4 & 37.0 & 38.4 & 35.7 & 35.6 & 33.9 \\
\hline Preanal length & 61.1 & 62.5 & 60.1 & 61.2 & 62.0 & 61.3 & 63.2 & 61.8 & 61.8 & 61.2 & 59.4 & 56.7 & 57.5 \\
\hline Caudal peduncle length & 16.4 & 18.1 & 16.7 & 16.7 & 19.7 & 18.4 & 16.6 & 15.9 & 19.0 & 15.0 & 18.1 & 15.7 & 15.6 \\
\hline Caudal peduncle depth & 10.9 & 10.8 & 11.3 & 11.2 & 11.1 & 10.3 & 11.0 & 11.6 & 11.6 & 11.1 & 11.1 & 10.5 & 11.0 \\
\hline \multicolumn{14}{|l|}{ As a percentage of $H L$} \\
\hline Snout length & 28.0 & 27.8 & 28.1 & 27.7 & 28.7 & 28.4 & 29.2 & 25.3 & 30.3 & 30.6 & 30.6 & 29.1 & 28.1 \\
\hline Eye diameter & 29.0 & 30.7 & 28.3 & 28.5 & 28.2 & 25.0 & 25.4 & 24.7 & 27.8 & 25.7 & 27.1 & 25.9 & 23.9 \\
\hline Interorbital width & 19.7 & 19.7 & 25.9 & 22.4 & 22.6 & 23.1 & 26.4 & 23.6 & 21.4 & 21.8 & 21.9 & 23.7 & 26.1 \\
\hline \multicolumn{14}{|l|}{ Meristic } \\
\hline Predorsal scales & 28 & 28 & 27 & 27 & 26 & 27 & 27 & 28 & 28 & 28 & 26 & 27 & 28 \\
\hline Lateral line scales & 78 & 76 & 75 & 78 & 75 & 76 & 75 & 77 & 77 & 78 & 76 & 77 & 77 \\
\hline $\begin{array}{l}\text { Scales between lateral line and pelvic } \\
\text { fin }\end{array}$ & 11 & 11 & 11.5 & 11.5 & 11.5 & 11 & 11 & 11 & 11 & 11 & 11 & 11 & 11 \\
\hline $\begin{array}{l}\text { Scales between lateral line and dorsal } \\
\text { fin }\end{array}$ & 14 & 14 & 13 & 13.5 & 13.5 & 13.5 & 14 & 14 & 14 & 14 & 13.5 & 13.5 & 13.5 \\
\hline Dorsal fin rays & 1,8 & 1,8 & $\mathrm{I}, 8$ & 1,8 & 1,8 & 1,8 & 1,8 & 1,8 & 1,8 & 1,8 & 1,8 & 1,8 & 1,8 \\
\hline Pectoral fin rays & $\mathrm{i}, 14$ & $\mathrm{i}, 14$ & $\mathrm{i}, 13$ & $\mathrm{i}, 14$ & $\mathrm{i}, 14$ & $\mathrm{i}, 14$ & $\mathrm{i}, 14$ & $\mathrm{i}, 14$ & $\mathrm{i}, 14$ & $\mathrm{i}, 14$ & $\mathrm{i}, 14$ & $\mathrm{i}, 14$ & $\mathrm{i}, 14$ \\
\hline Ventral fin rays & $\mathrm{i}, 8$ & $\mathrm{i}, 8$ & $\mathrm{i}, 8$ & i,9 & $\mathrm{i}, 9$ & $\mathrm{i}, 9$ & $\mathrm{i}, 9$ & $\mathrm{i}, 9$ & $\mathrm{i}, 9$ & $\mathrm{i}, 8$ & $\mathrm{i}, 8$ & $\mathrm{i}, 8$ & $\mathrm{i}, 8$ \\
\hline Anal fin rays & $\mathrm{ii}, 23$ & $\mathrm{ii}, 23$ & $\mathrm{ii}, 23$ & $\mathrm{ii}, 23$ & ii,22 & $\mathrm{ii}, 22$ & ii,23 & $\mathrm{ii}, 23$ & ii,22 & $\mathrm{ii}, 23$ & ii,23 & ii,23 & ii,23 \\
\hline
\end{tabular}

of urohyal bone of silver carp, Hypophthalmichthys molitrix (Val. 1844) for age determination. Current Science 79(1): $27-28$.

Menon, A.G.K. (1999). Check list - fresh water fishes of India. Occasional Paper No. 175. Records of the Zoological Survey of India, Kolkata. 366pp.

Silas, E.G. (1952). Further studies regarding Hora's Satpura hypothesis. Proceedings of the National Institute of Sciences of India 18(5): 423-448.
Singh, D.F. \& G.M. Yazdani (1992). Osteobrama bhimensis, a new cyprinid fish from Bhima River, Pune District, Maharahtra. Journal of the Bombay Natural History Society 89(1): 96-99.

Sykes, W.H. (1839). On the fishes of the Deccan. Proceedings of the General Meetings for Scientific Business of the Zoological Society of London 1838(6): 157-165.

Sykes, W.H. (1841). On the fishes of the Dukhun. Transactions of the Zoological Society of London 2: 349-378. 